\title{
Effects of Different Pollinators on Fruit Set and Quality Attributes of Texas Almond (Prunus dulcis L.) Cultivar
}

\author{
Mehmet YAMAN ${ }^{1}$ (D) Aydın UZUN ${ }^{1}$
}

${ }^{1}$ Erciyes University Seyrani Faculty of Agriculture Department of Horticulture, 38030, Kayseri/Turkey

\author{
Article History \\ Received 06 January 2021 \\ Accepted 23 February 2021 \\ First Online 01 March 2021
}

\section{Corresponding Author}

E-mail: mehmetyaman@erciyes.edu.tr

\author{
Keywords \\ Almond \\ Fruit set \\ Incompatibility \\ Pollinator \\ Texas
}

\begin{abstract}
There is a positive relationship between pollination and fruit yield of almonds. Since self-incompatibility is a major problem in almond cultivars, foreign pollinators are generally used in almonds to get high yield and quality. This study was conducted to investigate the effects of different pollinators (inbreed hybrid combinations) on fruit set and pomological characteristics of Texas almond cultivar in 2018 - 2019 growing seasons. Fruit set ratios varied between $3.6 \%$ (Texas $\times \mathrm{A} 3$ ) and $5.2 \%$ (Texas $\times \mathrm{A} 4$ ) in the first year of the study and between $8.0 \%$ (Texas $\times$ A3) and $13.2 \%$ (Texas $\times$ A2) in the second year. As the average of two years, the lowest fruit length $(32.03 \pm 2.45 \mathrm{~mm})$ was observed in Texas $\times$ A4 combination and the greatest fruit length (35.31 $\pm 3.05 \mathrm{~mm}$ ) was observed in Texas $\times A 1$ combination, whereas fruit width values varied between $19.37 \pm 2.43 \mathrm{~mm}$ and $23.79 \pm 1.33 \mathrm{~mm}$. Although pollinators influenced fruit mass values, the greatest value $(5.73 \pm 0.74 \mathrm{~g})$ was observed in Texas $\times$ A3 combination. It was concluded based on present findings that use of A2 cultivar as a pollinator in almond orchards established with Texas cultivar may have positive effects on fruit set.
\end{abstract}

\section{Introduction}

Turkey with diverse ecological conditions harbors several plant and fruit species (Ercisli, 2004). With such a great genetic diversity, Turkey is placed among precious countries and motherland of almond, apricot, plum, hazelnut-like important fruit species.

Almond (Prunus dulcis L.) with quite high nutritional values and various benefits on human health is grown in various parts of the world and in areas where there is no late spring frost in Turkey (Simsek, 2011). It either naturally grows or commercially grown in orchards as culture almond. There are several problems experienced in almond orchards of Turkey and such problems are mostly related to fruit set and yields (Boyaci and Çaglar, 2009). Flower and small-fruit drops are also the common problems of almond orchards.
Successful pollination is the first condition to be set for desired yield levels in fruit trees (Ortega et al., 2004). Receptivity of stigma, survival of ovule and perceiving time for pollen on ovary are the key parameters of a successful pollination and fertilization signaling. Pollens land on a receptive stigma, germinated pollens then generate a pollen tube and ultimately reach to surviving ovary to execute fertilization. Since the seeds are consumed in stone-fruits, all the bloomed flowers should turn into a fruit (100\% fruit set) for maximum yield (Boyaci and Çaglar, 2009). Growing and maintenance practices, ecological conditions, type of pollinator and cultivar genetics can directly affect the growth and yield of almond (Brittain et al., 2014; Klein et al., 2015). Self-incompatibility is the common case in majority of almond cultivars. Selfincompatibility is mostly related to S-allele status of the cultivar. Therefore, for optimum yields, S-allele 
status of relevant cultivar should be known and the cultivars with different $\mathrm{S}$-allele profiles should be selected in breeding programs. Besides yield, Sallele profiles also generate genetic diversity in almond breeding programs (Gómez et al., 2019). On the other hand, use of different pollinators influence fruit mass, shape and size. Previous researchers investigated the effects of different pollinators on fruit quality attributes of almonds (Dicanta et al., 2000), apples (Akkurt et al., 2019) and cherries (Cirtlik and Beyhan, 2012).

Besides pollinator cultivars, ecological conditions and cultural practices also significantly influence fruit set and yield in almonds. Since different ecological conditions are dominant in every region, even in different parts of the same region, almond cultivars do not exhibit the same yield and quality in every region (Kuden and Kuden, 2000; Yildiz and Perdahci, 2019).

In this study, effects of different hybrid combinations obtained through inbreed hybridizations of Texas almond cultivar on fruit set and some pomological characteristics of almonds were investigated.

\section{Material and Method}

\subsection{Material}

Experiments were conducted in collection orchards of Alata Horticultural Research Institute in the years 2018-2019. Texas almond cultivar was used as the parent material. The almond types encoded as A1, A2, A3 and A4 developed and registered at Alata Horticultural Research Institute were used. The flowering times of the mother and father parents partially match. The collection orchard $\left(36^{\circ} 37^{\prime} 12^{\prime \prime} \mathrm{N}, 34^{\circ} 19^{\prime} 40^{\prime \prime} \mathrm{E}\right)$ where the experiments were conducted was established in 1993. The orchard has different almond cultivars and there are 3 trees from each cultivar. Orchard soils have silty-loam texture. Trees are about 25 years old. Present almond cultivars are early flowering ones as compared to the other cultivars and mostly used as unripe almond. Meteorological data for flowering, pollination and fertilization periods are provided in Table1.

\subsection{Method}

Pollens of selected cultivars were gathered from non-burst flower buds at balloon stage. Pollens were rubbed onto emasculated flowers with the aid of a watercolor paint brush and hybridization procedures were performed accordingly. Hybridization was performed on 250 flowers for each hybridization combination. Routine cultural practices (irrigation, soil tillage, pruning) were performed accordingly. At the end of dormancy, $3 \mathrm{~kg}$ of $15-15-15 \mathrm{~N}-\mathrm{P}-\mathrm{K}$ fertilizer per tree were applied. Fruits were harvested at harvest maturity and harvested number of fruits were used to get fruit set ratios for different hybrid combinations. Hybridizations were performed on 20.02.2018 and 23.02.2019; harvests were practiced on 10.07.2018 and 13.07.2019. Pomological characteristics including fruit mass, width and length were determined (Gulcan, 1985; Hanine et al., 2016). Measurements were performed on 10 fruits of each hybrid combination. Experimental data were subjected to statistical analyses using SPSS software and significant means were compared with Duncan's multiple range test at $\mathrm{P}<0.05$ significance level.

\section{Results and Discussion}

\subsection{Fruit set ratios}

Fruit set ratios of the years 2018 and 2019 varied with the pollinators. Fruit set ratios varied between $3.6-5.2 \%$ in 2018. Based on pollinators, fruit set ratio was $4.2 \%$ in Texas $\times \mathrm{A} 1$ combination, $4.4 \%$ in Texas $\times$ A2 combination, $3.6 \%$ in Texas $\times$ A3 combination and $5.2 \%$ in Texas $\times$ A4 combination (Table 2).

Table 1. Meteorological data for experimental years

\begin{tabular}{clrrrrrrrr}
\hline \multirow{2}{*}{ Years } & \multicolumn{2}{c}{$\begin{array}{c}\text { Wind speed } \\
\left(\mathrm{m}^{-\mathrm{s}}\right)\end{array}$} & \multicolumn{2}{c}{$\begin{array}{c}\text { Precipitation } \\
(\mathrm{mm})\end{array}$} & \multicolumn{2}{c}{$\begin{array}{c}\text { Max. temperature } \\
\left({ }^{\circ} \mathrm{C}\right)\end{array}$} & \multicolumn{2}{c}{$\begin{array}{c}\text { Min. temperature } \\
\left({ }^{\circ} \mathrm{C}\right)\end{array}$} \\
\cline { 2 - 11 } & & February & March & February & March & February & March & February & March \\
\hline \multirow{2}{*}{2018} & Max. & 1.9 & 4.0 & 19.00 & 11.80 & 21.3 & 27.3 & 10.5 & 15.5 \\
\cline { 2 - 11 } & Min. & 0.5 & 0.8 & 0.80 & 0.20 & 16.1 & 18.2 & 4.0 & 6.7 \\
\cline { 2 - 11 } & Mean & 1.0 & 1.5 & 1.57 & 0.44 & 18.2 & 21.0 & 7.3 & 9.9 \\
\hline \multirow{2}{*}{2019} & Max. & 2.6 & 1.7 & 146.80 & 73.0 & 19.4 & 22.7 & 9.9 & 11.3 \\
\cline { 2 - 11 } & Min. & 0.8 & 0.7 & 0.20 & 0.20 & 11.5 & 15.2 & 2.3 & 0.9 \\
\cline { 2 - 11 } & Mean & 1.4 & 1.3 & 5.20 & 2.30 & 16.4 & 18.4 & 6.1 & 6.9 \\
\hline
\end{tabular}

Table 2. Fruit set ratios of 2018

\begin{tabular}{lccc}
\hline Combination & Number of pollinated flowers & Number of fruit sets & Fruit set ratio (\%) \\
\hline Texas $\times$ A1 & 250 & 10 & 4.0 \\
Texas $\times$ A2 & 250 & 11 & 4.4 \\
Texas $\times$ A3 & 250 & 9 & 3.6 \\
Texas $\times$ A4 & 250 & 13 & 5.2 \\
\hline
\end{tabular}


In 2019, fruit set ratios and number of fruit sets were greater than the year 2018. The lowest fruit set ratio $(8.0 \%)$ was observed in Texas $\times \mathrm{A} 3$ combination and the greatest fruit set ratio (13.2\%) was observed in Texas $\times$ A2 combination (Table 3). Differences in fruit set ratios of the experimental years were mostly attributed to climate parameters. Previous researchers indicated the effects of ecological conditions on fruit set in almond orchards (Kuden and Kuden, 2000; Yildiz and Perdahci, 2019). Present findings well comply with the results of earlier studies.

Pollinators influence fruit set of almonds. Despite the use of a foreign pollinator, fruit sets may vary based on fruit loads and nutritional status of almond trees (Cunningham et al., 2019). Such difference can be noticed in subsequent years of heavy fruitload years (Tombesi et al., 2017). Medium fruit set ratios were observed in almond breeding programs conducted with different almond cultivars (Acar et al., 2014).

Positive impacts of pollinator cultivars on fruit sets were reported for different species. In a previous study conducted to investigate the effects of different pollinators on fruit set and quality attributes of Canino apricot cultivar, fruit set ratios varied between $18.04-21.70 \%$ based on pollinator cultivars (Taha and Sheriff, 2015). Another study conducted with persimmons, "Risoli" and "Moro" pollinators had greater effects on fruit set than openpollinating persimmons (Yildiz and Kaplankiran, 2013). Present findings show different with the results of earlier studies reporting varying fruit set ratios with the pollinator cultivars and years. The effect of climate and the use of different genotypes can be shown as the reason for this difference.

\subsection{Pomological characteristics}

During 2018, pomological characteristics such as fruit length and width values of hybrid combinations were found to be significant (Table 3). Fruit lengths of hybrid combinations varied between $32.26 \pm 1.71 \mathrm{~mm}$ and $33.91 \pm 2.37 \mathrm{~mm}$. Fruit length of open-pollinating Texas cultivar was measured as $30.22 \pm 1.66$. The lowest fruit width $(21.85 \pm 2.75 \mathrm{~mm})$ was observed Texas $\times$ A2 combination and the greatest fruit width $(23.79 \pm 1.33 \mathrm{~mm})$ was observed in Texas $\times$ A4 combination. Fruit mass values also significantly varied with the father parent. While the Texas $\times$ A2 combination had the lowest fruit mass with $2.99 \pm 0.38 \mathrm{~g}$, Texas $\times \mathrm{A} 4$ combination had the greatest fruit mass with $3.60 \pm 0.42 \mathrm{~g}$. Regarding fruit mass values, all combinations had greater values that open pollination (Table 4).

In 2019, significant differences were observed in fruit length, width and mass values of the hybrid combinations. The lowest fruit length $(28.26 \pm 2.48$ $\mathrm{mm}$ ) was observed in Texas $\times$ A3 combination. The lowest fruit width $(19.37 \pm 2.43 \mathrm{~mm})$ was observed again in Texas $\times$ A3 combination. However, despite the lowest fruit length and width, Texas $\times A 3$ combination had the greatest fruit mass with $5.73 \pm 0.74 \mathrm{~g}$ (Table 5). As compared to openpollinating Texas cultivar, different pollinators had significant positive effects on fruit length and weight, but insignificant effects on fruit width. Different effects of the same pollinators in different years can be attributed to differences in climate parameters.

Sumbul and Bayazit (2019) reported fruit lengths of different almond cultivars as between 12.81$19.35 \mathrm{~mm}$, fruit widths as between 15.43-27.12 mm and fruit mass values as between $1.55-6.34 \mathrm{~g}$. In

Table 3. Fruit set ratios of 2018

\begin{tabular}{lccr}
\hline Combination & Number of pollinated flowers & Number of fruit sets & Fruit set ratio (\%) \\
\hline Texas $\times$ A1 & 250 & 21 & 8.4 \\
Texas $\times$ A2 & 250 & 33 & 13.2 \\
Texas $\times$ A3 & 250 & 20 & 8.0 \\
Texas $\times$ A4 & 250 & 22 & 8.8 \\
\hline
\end{tabular}

Table 4. Pomological characteristics of hybrid combinations in 2018

\begin{tabular}{llll}
\hline Combination & Fruit length $(\mathrm{mm})$ & Fruit width $(\mathrm{mm})$ & Fruit mass $(\mathrm{g})$ \\
\hline Texas & $30.22 \pm 1.66 \mathrm{~b}$ & $24.51 \pm 2.83 \mathrm{a}$ & $2.94 \pm 0.33 \mathrm{c}$ \\
Texas $\times$ A1 & $32.26 \pm 1.71 \mathrm{a}$ & $22.85 \pm 1.37 \mathrm{ba}$ & $3.34 \pm 0.33 \mathrm{ba}$ \\
Texas $\times$ A2 & $32.58 \pm 1.71 \mathrm{a}$ & $21.85 \pm 2.75 \mathrm{~b}$ & $2.95 \pm 0.38 \mathrm{bc}$ \\
Texas $\times$ A3 & $33.91 \pm 2.37 \mathrm{a}$ & $23.56 \pm 2.38 \mathrm{ba}$ & $3.11 \pm 0.50 \mathrm{bc}$ \\
Texas $\times$ A4 & $33.16 \pm 2.05 \mathrm{a}$ & $23.79 \pm 1.33 \mathrm{ba}$ & $3.60 \pm 0.41 \mathrm{a}$ \\
Mean & $32.45 \pm 2.21$ & $23.31 \pm 2.32$ & $3.20 \pm 0.45$ \\
\hline
\end{tabular}

Table 5. Pomological characteristics of hybrid combinations in 2019

\begin{tabular}{llll}
\hline Combination & Fruit length $(\mathrm{mm})$ & Fruit width $(\mathrm{mm})$ & Fruit mass $(\mathrm{g})$ \\
\hline Texas & $32.38 \pm 1.84 \mathrm{~b}$ & $22.12 \pm 1.68 \mathrm{a}$ & $3.66 \pm 0.71 \mathrm{c}$ \\
Texas $\times$ A1 & $35.31 \pm 3.05 \mathrm{a}$ & $23.68 \pm 2.66 \mathrm{a}$ & $3.26 \pm 1.09 \mathrm{c}$ \\
Texas $\times$ A2 & $33.47 \pm 3.26 \mathrm{ba}$ & $23.52 \pm 3.02 \mathrm{a}$ & $4.53 \pm 1.00 \mathrm{~b}$ \\
Texas $\times$ A3 & $28.26 \pm 2.48 \mathrm{c}$ & $19.37 \pm 2.43 \mathrm{~b}$ & $5.73 \pm 0.74 \mathrm{a}$ \\
Texas $\times$ A4 & $32.03 \pm 2.45 \mathrm{~b}$ & $21.91 \pm 1.97 \mathrm{a}$ & $3.64 \pm 0.65 \mathrm{c}$ \\
Mean & $32.37 \pm 3.43$ & $22.18 \pm 2.76$ & $4.13 \pm 1.20$ \\
\hline
\end{tabular}


another study conducted on almonds, fruit mass values were reported as between $7.74-3.40 \mathrm{~g}$ (Khadivi et al., 2019). In a previous study conducted on adaptation of almond cultivars, fruit mass values were reported as between $1.62-4.15 \mathrm{~g}$, fruit lengths as between $32.30-38.72 \mathrm{~mm}$ and fruit widths as between 16.00-26.36 mm (Yildiz and Perdahci, 2019).

\section{Conclusion}

Present findings on fruit mass, length and widths comply with the findings of previous studies. Partial differences were mostly attributed to differences in cultivars, pollinators, and climate parameters. Pollination problems are mostly resulted from insufficient development of pollens at low temperatures (below $10^{\circ} \mathrm{C}$ ) during the flowering period or inability of pollen to germinate even if they sufficiently developed, unacceptance of pollens by stigma. Even if the pollination was realized, such problems also end up with small fruit sizes, thus reduce quality. On the other hand, besides ecological conditions, cultural practices (irrigation, fertilization, pruning, tree age) and yield potential also significantly influence fruit size. Almond is a significant income-generating fruit both in the world and in Turkey. It was concluded based on present findings that use of pollinator cultivars had significant effects on fruit sets and quality attributes. Present pollinators can be recommended for new almond orchards to be established with Texas cultivar for high yields and quality attributes.

\section{Acknowledgments}

This study was supported by the Scientific Research Projects Department of Erciyes University (Project No: FDK-2018-8044) and authors thanks to Erciyes University for the financial support. The authors are also grateful to Prof. Dr. Zeki GOKALP (a Certified-Notarized English Translator and an expert in Biosystems Engineering) for his critical reading and through syntactic corrections of the manuscript.

\section{References}

Acar, I.S., Arpacı, H.S., Atli, S., Kafkas, S., Eti, S.A., \& Çağlar, A. (2014). Breeding self-productive and late flowering almond varieties through hybridization. Turkey VI. National Horticulture Congress. 4-8 October 2011, Sanliurfa, Vol 1:42-48.

Akkurt, E., Mertoglu, K., \& Evrenosoglu, Y. (2020). Effects of different pollinator cultivars on fruit set and different fruit quality characteristics on vista bella apple cultivar. Anadolu, 30:284-294.

Boyaci, S., \& Caglar, S. (2009). The effect of fall foliar boron application on the fruit set of different almond cultivars. University of Kahramanmaraş Sütçü Imam Journal of Natural Science, 12:36-43, (in Turkish).
Brittain, C., Kremen, C., Garber, G., \& Klein, A.M. (2014). Pollination and plant resources change the nutritional quality of almonds for human health. PLoS One, 9:e90082.

Cirtlik, B.K., \& Beyhan, N. (2012). An investigation of the possible use of some important local sweet cherry cultivars grown in amasya province as pollinizers for 0900 ziraat cultivar. Anadolu Journal of Agricultural Scince, 27:64-69, (in Turkish).

Cunningham, A.S., Evans, M.J., Neave, M., Armstrong, J., \& Barton, J.B. (2019). Pollination and resource limitation as interacting constraints on almond fruit set. Plant Biology, 22:113-119.

Dicenta, F., Martínez-Gómez, P., \& Ortega, E. (2000). Cultivar pollinizer does not affect almond flavor. HortScience, 35:1153-1154.

Ercisli, S. (2004). A short review of the fruit germplasm resources of Turkey. Genetic Resources and Crop Evolution, 51:419-435.

Gómez, M.E., Dicenta, F., Batlle, I., Romero, A., \& Ortega, E. (2019). Cross-incompatibility in the cultivated almond (Prunus dulcis): Updating, revision and correction. Scientia Horticulturae, 245:218-223.

Gulcan, R. (1985). Descriptor list for almond (Prunus amygdalus). Revised Edn.). International Board for Plant Genetic Resources, Rome.

Hanine, H., Zinelabidine, L.H., Kodad, O., H'ssaini, H., Haddioui, A., \& Ennahli, S. (2016). Pomological, phenotypical diversity and biochemical characterization of fortheen almond morphotypes from Morocco. Options Méditerranéennes, A, (119).

Khadivi, A., Goodarzi, S., \& Sarkhosh, A. (2019). Identification of late-blooming almond (Prunus dulcis L.) genotypes with high kernel quality. Euphytica, 215:166.

Klein, A.M., Hendrix, S.D., Clough, Y., Scofield, A., \& Kremen, A. (2015). Interacting effects of pollination, water and nutrients on fruit tree performance. Plant Biology, 17:201-208.

Kuden, A.B., \& Kuden, A. (2000). Badem Yetiştiriciliği. TÜBiTAK-TARP Yayınları. Ankara, 18s, (in Turkish).

Ortega, E., Egea, J., \& Dicenta, F. (2004). Effective pollination period in almond cultivars. HortScience, 39:19-22.

Simsek, M. (2011). Almond selection in Cinar District. Science Journal of Bingöl University, 1:32-36, (in Turkish).

Sumbul, A., \& Bayazit, S. (2019). Pomological and chemical attributes of almond genotypes selected from Hatay Province. International Journal of Agriculture and Wildlife Science, 5:1-10.

Taha, N.M., \& Sherif, H.M. (2015). Increasing fruit set, yield and fruit quality of "Canino" apricot trees under two different soil conditions. Current Journal of Applied Science and Technology, 10:1-18.

Tombesi, S., Lampinen, B.D., Metcalf, S., \& Dejong, T.M. (2017). Yield in almond is related more to the abundance of flowers than the relative number of flowers that set fruit. California Agriculture, 71:68-74.

Yildiz, E., \& Kaplankiran, M. (2013). The effect of different pollinators on fruit attitude and quality in irojiro" persimmon variety. Alatarım, 12:26-32.

Yildiz, E., \& Perdahci, C.E. (2019). Adaptation of some almond cultivars in Uşak ecological conditions. Journal of Agricultural and Animal Sciences, 2:11-19. 